\title{
Anti-Obesity Effect of Garlic-added Kochujang in 3T3-L1 Adipocytes
}

\author{
Chang-Suk Kong ${ }^{1}$ and Kun-Young Park ${ }^{2 \dagger}$ \\ ${ }^{1}$ Marine Bioprocess Research Center, Pukyong National University, Busan 608-737, Korea \\ ${ }^{2}$ Dept. of Food Science and Nutrition, Pusan National University, Busan 609-735, Korea
}

\begin{abstract}
In order to develop a functionally improved kochujang with antiobesity effects, garlic-added kochujang was prepared with freeze-dried garlic powder and followed by fermentation for 60 days at $30^{\circ} \mathrm{C}$. Antiobesity effect of the garlic-added kochujang was investigated by measuring the leptin secretions and mRNA expression levels of obesity-related gene such as TNF $\alpha$, PPAR $\gamma$, C/EBP $\alpha$, and SREBP1c, in cultured 3T3-L1 adipocytes. Fermentation of garlic-added kochujang led to decreased levels of leptin secretions and reduced the mRNA expression levels of TNFo, PPAR $\gamma, \mathrm{C} / \mathrm{EBP} \alpha$, and SREBP1c in the 3T3-L1 adipocytes. Accordingly, these results suggest that the addition of garlic to kochujang has a potential as a valuable functional food for controlling obesity.
\end{abstract}

Key words: garlic, kochujang, 3T3-L1 adipocytes, anti-obesity, leptin

\section{INTRODUCTION}

Recently, the obesity rate has been increasing noticeably worldwide, so that obesity has been important heath issue. Obesity is a major factor in increasing the risk of serious diseases such as heart disease, hypertension, stroke, cancer, diabetes, and osteoarthritis $(1,2)$. That is why numerous studies have attempted to find functional foods or agents from such oriental foods or medicines, including Korean traditional fermented foods for weight control. The ob-protein, leptin, is secreted from adipose tissue and may be important in the development of obesity (3-5). Leptin concentration in the serum is directly related to the amount of body fat and the amount of energy stored in adipose tissue $(6,7)$. Adipocyte reserve energy as well as the secretion of various transcription factors such as leptin, aP2, TNF $\alpha$, PPAR $\gamma, \mathrm{C} / \mathrm{EBP} \alpha$, and SREBP1c are major transcription factors for adipogenic response.

Kochujang, a fermented red pepper soybean paste, is one of the most famous traditional Korean fermented foods. Generally, traditional kochujang is prepared with glutinous rice, meju (fermented soybean blocks), red pepper powder and salt. The unique hot, sweet, salty and savory tastes as well as color and flavors of kochujang are produced by the actions of microorganisms such as koji mold, bacteria, and yeasts during the fermentation process $(8,9)$.

Garlic (Allium sativum) is a member of lily family that has been cultivated by humans as a food plant for over 10,000 years. Since ancient times, numerous medicinal properties of garlic have been discovered. It has been reported that garlic and its associated sulfur compounds suppress weight gain, and TG and cholesterol concentrations. They also affect the normalization of plasma lipids, reduction of blood pressure and glucose, and inhibition of platelet aggregation (10-14). Sulfur compounds from garlic are known as alliin, allicin (diallyl thiosulfinate), diallyl sulfinate (DAS), diallyl disulfinate (DADS), etc.

In this study, in order to develop a functionally improved kochujang with an antiobesity effects, garlic-added kochujang was made with freeze-dried garlic powder. Antiobesity effect of the garlic-added kochujang was investigated by measuring the leptin secretion levels and the mRNA expression levels of obesity-related genes such as TNF $\alpha$, PPAR $\gamma, \mathrm{C} / \mathrm{EBP} \alpha$, and SREBP1c in cultured 3T3-L1 adipocytes.

\section{MATERIALS AND METHODS}

\section{Ingredients and preparations of kochujang}

Glutinous flour, malt flour, meju flour, and salt were purchased at a local market in Busan, Korea. Red pepper powder and garlic were purchased from Uiseong, Gyeongsangbuk-do, Korea. Kochujang was prepared by the standardized method (15) and fermented for 60 days at $30^{\circ} \mathrm{C}$. Garlic was freeze-dried, powdered, and added in ratios of $0 \%$ and $3 \%$ during the preparation of kochujang and the prepared garlic-added kochujang was fer-

${ }^{\dagger}$ Corresponding author. E-mail: kunypark@pusan.ac.kr

Phone: +82-51-510-2839, Fax: +82-51-514-3138 
mented for 60 days at $30^{\circ} \mathrm{C}$. The prepared kochujang was freeze-dried, powdered, and extracted 3 times with 20 -fold methanol. The methanol extract was concentrated using a vacuum rotary evaporator and followed by dissolution in dimethylsulfoxide (DMSO).

\section{Cell culture and adipocyte differentiation}

3T3-L1 mouse cells were purchased from the American Type Culture Collection (ATCC, USA). Dulbecco's Modified Eagle Medium (DMEM) and fetal bovine serum (FBS) were purchased from Gibco Service Co. (USA). Methylisobutylxanthine (IBMX), dexamethasone (DEX), and insulin (INS) were purchased from sigma Chemicals Co. (USA). The mouse 3T3-L1 preadipocytes were grown to confluence in Dulbecco's Modified Eagle Medium (DMEM) with 10\% fetal bovine serum (FBS) at $37^{\circ} \mathrm{C}$ in a humidified atmosphere of $5 \% \mathrm{CO}_{2}$. At 1 day post-confluence (designated "day 0"), cell differentiation was induced with a mixture of methylisobutylxanthine $(0.5 \mathrm{mM})$, dexamethasone $(0.25 \mu \mathrm{M})$, and insulin $(5 \mu \mathrm{g} / \mathrm{mL})$ in DMEM containing $10 \%$ FBS. On day 2 and day 4, the medium was replaced with DMEM containing $10 \%$ FBS and insulin $(5 \mu \mathrm{g} / \mathrm{mL})$ only. On day 6, thereafter the medium consisted of only DMEM plus $10 \% \mathrm{FBS}$, which was subsequently replaced every 2 days. The garlic-added kochujang extracts were used to treat adipocytes at the concentration of $1 \mathrm{mg} / \mathrm{mL}$ at day 8 after inducing differentiation. After the $24 \mathrm{hr}$, the medium was removed for analysis of leptin.

\section{Measurement of leptin levels}

Measurement of leptin levels was performed with a sandwich enzyme-linked immunosorbent assay (ELISA). Anti-mouse leptin, recombinant mouse leptin, and biotinylated anti-mouse leptin antibodies were purchased from R\&D Systems (MN, USA) (16).

RNA isolation, RNA extraction and reverse transcription-polymerase chain reaction

Total RNA was isolated from differentiated 3T3-L1 adipocytes using a Trizol reagent (Invitrogen Co., Carlsbad, CA, USA). One $\mu \mathrm{g}$ of total RNA was used for first-strand cDNA synthesis using Superscript II reverse transcriptase (BD Bioscience, Palo Alto, CA). Reverse transcription was performed at $30^{\circ} \mathrm{C}$ for $10 \mathrm{~min}$, $42^{\circ} \mathrm{C}$ for $30 \mathrm{~min}$, and $99^{\circ} \mathrm{C}$ for $5 \mathrm{~min}$ to inactivate the avian myeloblastosis virus RTXL. Primers to specifically amplify the genes of interest are shown as Table 1 . Amplification was performed in a master-cycler (Eppendorf, Hamburg, Germany) with denaturing at $94^{\circ} \mathrm{C}$ for $1 \mathrm{~min}$, annealing at $54^{\circ} \mathrm{C}$ for $1 \mathrm{~min}$, extension at $72^{\circ} \mathrm{C}$ for $30 \mathrm{sec}$ for 25 cycles and finally $72^{\circ} \mathrm{C}$ for $7 \mathrm{~min}$. The amplified PCR products were run in $1.0 \%$ agarose gels and stained with ethidium bromide ( $\mathrm{EtBr})$, and visualized under UV light. The intensities of the bands were estimated by densitometry (Multi Gauge V3.0 software, Fujifilm Life Science, Tokyo, Japan).

\section{Statistical analysis}

Data were expressed as mean \pm standard error values $(n=3)$. Means with different letters are significantly different $(p<0.05)$ by Duncan's multiple range tests. Each experiment was replicated at least 3 times.

\section{RESULTS AND DISCUSSION}

\section{Effect of garlic-added kochujang on leptin secretions during fermentation}

In order to determine whether adding garlic affects the antiobesity properties of kochujang, garlic-added kochujang was prepared and fermented for 60 days. Since garlic includes a lot of active sulfur-compounds, one would expect that the addition of garlic powder to kochujang would induce a suppressive effect on lipid accumulation. The circulating leptin levels are correlated with adipose tissue mass $(17,18)$. Therefore, the adipogenic response of garlic-added kochujang in differentiated adipocytes was determined by measuring the amount of leptin released in the medium by treatment

Table 1. Gene-specific primers used for the RT-PCR

\begin{tabular}{|c|c|c|}
\hline Gene name & Direction & Sequence \\
\hline \multirow{2}{*}{$\mathrm{TNF} \alpha$} & Forward & 5'-AGG CCT TGT GTT GTG TTT CCA-3' \\
\hline & Reverse & 5'-TGG GGG ACA GCT TCC TTC TT-3' \\
\hline \multirow{2}{*}{ PPAR $\gamma$} & Forward & 5'-GAG ATG CCA TTC TGG CCC ACC AAC TTC GG-3' \\
\hline & Reverse & 5'-TAT CAT AAA TAA GCT TCA ATC GGA TGG TTC-3' \\
\hline \multirow{2}{*}{$\mathrm{C} / \mathrm{EBP} \alpha$} & Forward & 5'-TGC TGG AGT TGA CCA GTG ACA A-3' \\
\hline & Reverse & 5'-AAA CCA TCC TCT GGG TCT CC-3' \\
\hline \multirow{2}{*}{ SREBP1c } & Forward & 5'-ATC GGC GCG GAA GCT GTC GGG GTA GCG TC-3' \\
\hline & Reverse & 5'-ACT GTC TTG GTT GTT GAT GAG CTG GAG CAT-3' \\
\hline \multirow{2}{*}{$\beta$-actin } & Forward & 5'-AGC CAT GTA CGT AGC CAT CC-3' \\
\hline & Reverse & 5'-TCC CTC TCA GCT GTG GTG GTG AA-3' \\
\hline
\end{tabular}


with garlic-added kochujang (Fig. 1). Fermentation of the garlic-added kochujang reduced leptin secretion compared to that of the control adipocyte.

Effect of kochujang and gartic-added kochujang on leptin secretion

To determine whether the addition of garlic affects the leptin secretion of kochujang in 3T3-L1 adipocytes, leptin level secreted in cultured media treated with garlic-added kochujang was compared to that of control kochujang (Fig. 2). Here, traditional kochujang prepared without garlic was used as a control kochujang. Also the control kochujang and garlic-added kochujang fer-

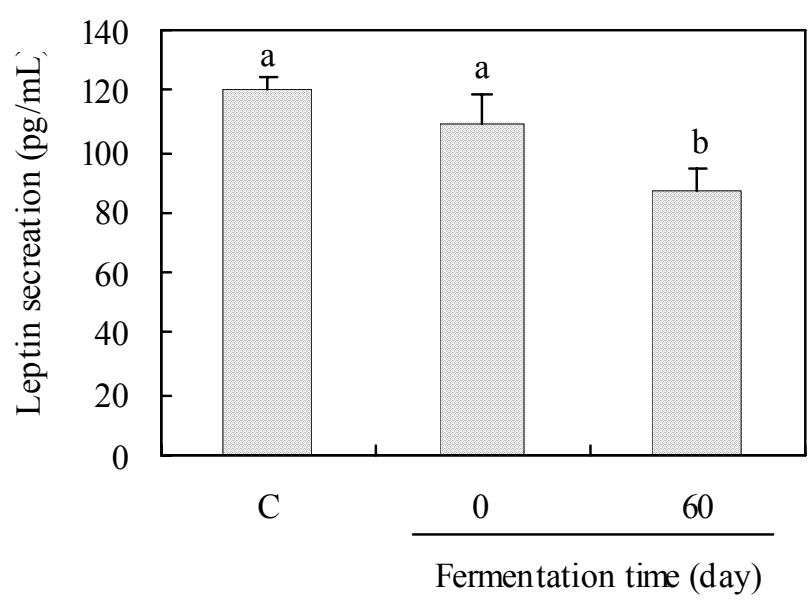

Fig. 1. Changes in leptin secretion of garlic-added kochujang during fermentation. Adipocytes were treated for $24 \mathrm{hr}$ at "day 8 " after inducing differentiation with vehicle alone (control: $5 \mathrm{mM}$ methylisobutyxanthine, $0.25 \mu \mathrm{M}$ dexamethanesone, 10 $\mu \mathrm{g} / \mathrm{mL}$ insulin) or $1 \mathrm{mg} / \mathrm{mL}$ of kochujang fermented for 60 days. Data are expressed as mean \pm standard error values $(n=3)$. Means with different letters are significantly different $(\mathrm{p}<0.05)$ by Duncan's multiple range test.

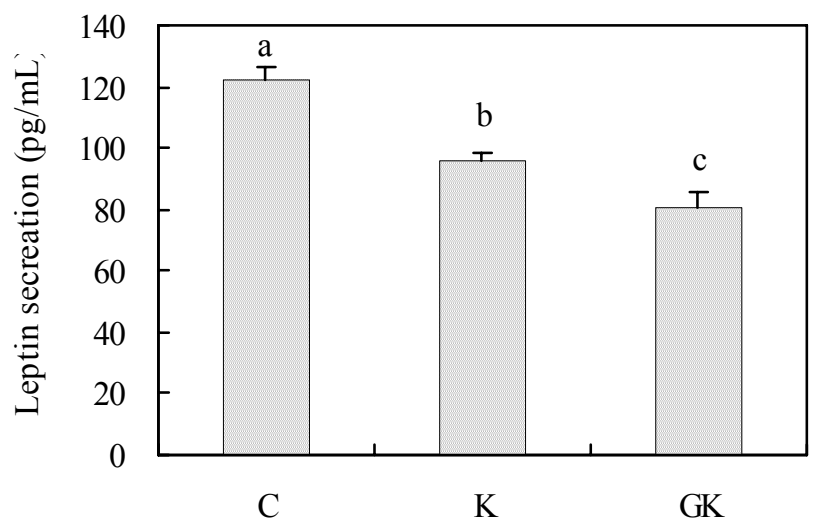

Fig. 2. Additional effect of garlic powder on leptin secretion of kochujang. Data are expressed as mean \pm standard error values $(n=3)$. Means with different letters are significantly different $(\mathrm{p}<0.05)$ by Duncan's multiple range test. K: control kochujang fermented for 60 days, GK: garlic-added kochujang (3\%) fermented for 60 days. mented 60 days were used for comparative analysis. Leptin secretions of control kochujang and garlic-added kochujang were decreased by $34 \%$ and $48 \%$, respectively, compared to that of the control adipocytes. The addition of garlic powder into the kochujang reduced leptin secretion in the medium. This result demonstrated that making garlic-added kochujang has the potential to improve its antiobesity effects. It might be due to a synergistic effect between garlic and the products created by fermentation of kochujang. As possible active components responsible for the antiobesity effect of kochujang, capsaicin in red pepper powder, isoflavonoide produced from meju, and some glycoside products caused by fermentation could be included. Several studies have reported on antiobesity effects of fermented traditional kochujang as well as on the decrease of inbody weight, serum lipids, and body fat gain (19-22). Similar to traditional kochujang, commercial kochujang also decreased leptin secretion and adipocytes size in 3T3-L1 adipocytes by modulating adipogenesis and lipolysis (23). Also, various biological activities of garlic and its associated sulfur compounds such as alliin, allicin (diallyl thiosulfinate), DAS, DADS, have been reported (24-31). The effects of garlic powder on reducing total lipids, TG, and cholesterol contents were studied (11-14). In vivo, reducing effects of garlic on weight gain, TG and cholesterol contents, and lipid values of adipose tissue were reported (30).

\section{Effect of garlic-added kochujang on obesity related gene expressions}

TNF $\alpha$ is produced by adipocyte tissue and its mRNA level increases with the increasing adiposity. TNF $\alpha$ increases not only both leptin gene expression and leptin secretion in 3T3-L1 adipocytes but also lipolysis and released free fatty acid (32). Therefore, the mRNA expression levels of TNF $\alpha$ in the differentiated adipocytes treated with the control kochujang and garlic-added kochujang were compared (Fig. 3). Treatment with garlic-added kochujang in matured adipocytes markedly suppressed their TNF $\alpha$ expression compared with that of the control adipocytes. That is, adding of garlic during kochujang preparation might be associated with the reduced cellular lipid accumulation mediated by TNFa.

PPAR $\gamma$ is a member of the nuclear receptor superfamily of transcription factors and is predominantly expressed in adipose tissue. These transcription factors appear to function as dominant activators of adipocyte differentiation (33). PPAR $\gamma$ is a major coordinator of adipocyte gene expression and differentiation (34). PPAR $\gamma$ is induced prior to the transcriptional activation of most adipo-cyte-specific genes, and the expression of PPAR $\gamma$ 

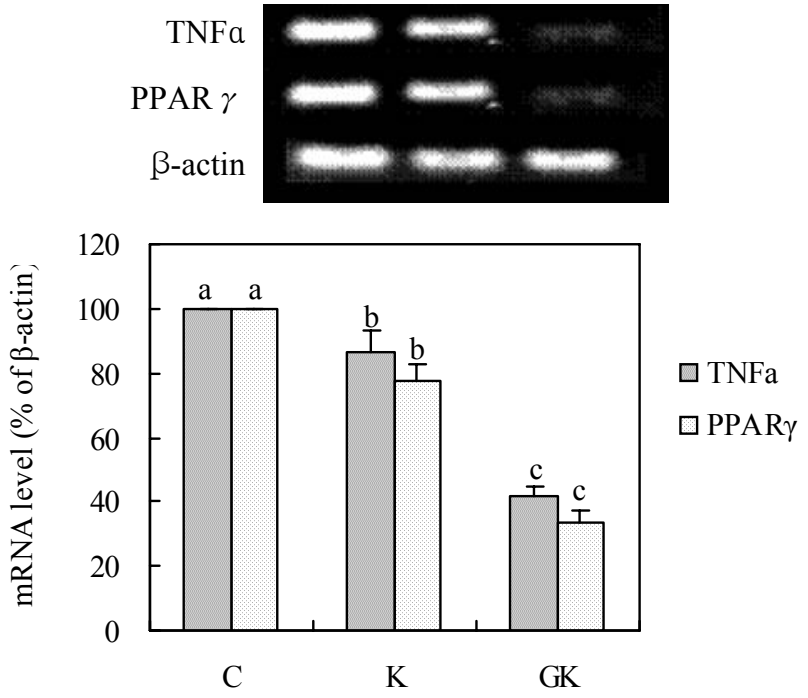

Fig. 3. Effects of garlic-added kochujang on TNF $\alpha$ and PPAR $\gamma$ mRNA expression levels in 3T3-L1 adipocytes. Starting at day 8 after inducing differentiation, adipocytes were cultured with or without $1 \mathrm{mg} / \mathrm{mL}$ of control kochujang and garlic-added kochujang for $24 \mathrm{hr}$. Data are expressed as mean \pm standard error values $(n=3)$. Means with different letters are significantly different $(\mathrm{p}<0.05)$ by Duncan's multiple range test. $\mathrm{C}$ : untreated control adipocyte $(0.5 \mathrm{mM}$ methylisobutyxanthine, $0.25 \mu \mathrm{M}$ dexamethanesone, $10 \mu \mathrm{g} / \mathrm{mL}$ insulin), $\mathrm{K}$ : control kochujang fermented for 60 days, GK: garlic-added kochujang (3\%) fermented for 60 days.

is sufficient to induce growth arrest and to initiate adipogenesis in exponentially growing fibroblast cell lines (35). Effect of garlic-added kochujang on the mRNA expression level of PPAR $\gamma$ was evaluated by using RT-PCR analysis (Fig. 3). The mRNA expression of PPAR $\gamma$ of the control kochujang and garlic-added kochujang was decreased by $19 \%$ and $69 \%$, respectively, compared to that of the control adipocytes.

PPAR $\gamma$ is expressed early in the differentiation of 3T3-L1 adipocytes and prior to C/EBP $\alpha$ (36). Overexpression of $\mathrm{C} / \mathrm{EBP} \alpha$ as well as PPAR $\gamma$ can induce adipocyte differentiation (37). In the present study, fermentation of garlic-added kochujang as well as control kochujang reduced the mRNA expression level of $\mathrm{C} / \mathrm{EBP} \alpha$ (Fig. 4). SREBP1c is also one of important transcription factors for adipogenesis. The expression of SREBP1c can induce endogenous PPAR $\gamma$ mRNA expression in 3T3-L1 adipocytes. Treatment with control kochujang and garlic-added kochujang led to down-regulation of SREBP1c mRNA (Fig. 4). However, there were a little significant difference between the adipocytes treated with control kochujang and garlic-added kochujang. In conclusion, fermentation of kochujang reduced expression levels of adipogenic genes such as PPAR $\gamma$, $\mathrm{C} / \mathrm{EBP} \alpha$ and SREBP1c and theirs levels were more in-
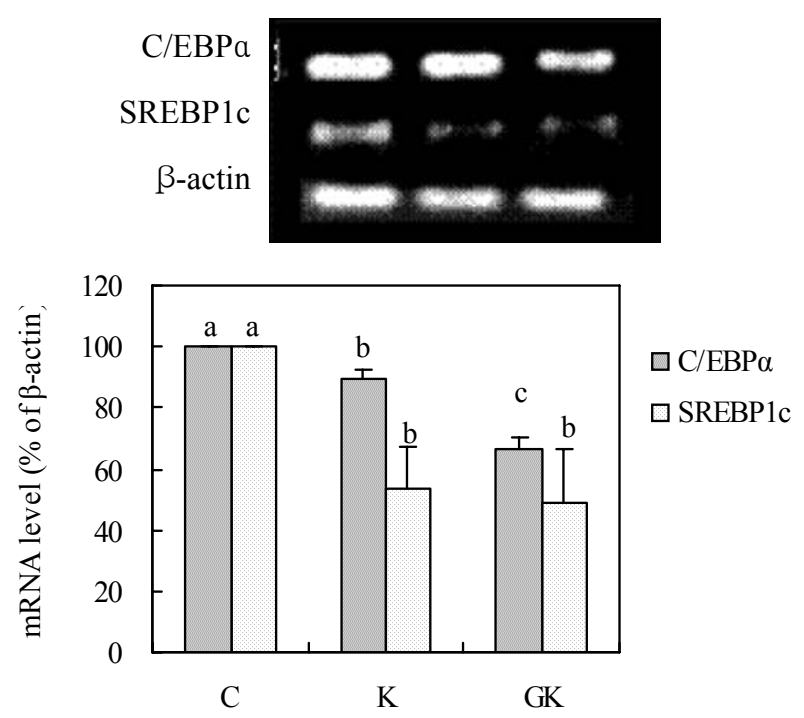

Fig. 4. Effects of garlic-added kochujang on $\mathrm{C} / \mathrm{EBP} \alpha$ and SREBP1c mRNA expression levels in 3T3-L1 adipocytes. Starting at day 8 after inducing differentiation, adipocytes were cultured with or without $1 \mathrm{mg} / \mathrm{mL}$ of control kochujang and garlic-added kochujang for $24 \mathrm{hr}$. Data are expressed as mean \pm standard error values $(n=3)$. Means with different letters are significantly different $(\mathrm{p}<0.05)$ by Duncan's multiple range test. C: untreated control adipocyte $(0.5 \mathrm{mM}$ methylisobutyxanthine, $0.25 \mu \mathrm{M}$ dexamethanesone, $10 \mu \mathrm{g} / \mathrm{mL}$ insulin), K: control kochujang fermented for 60 days, GK: garlic-added kochujang (3\%) fermented for 60 days.

hibited by garlic-added kochujang. Therefore, antiobesity effect of garlic-added kochujang might be due to inhibiting regulation promoters of several adipogenic genes such as leptin though $\operatorname{PPAR} \gamma, \mathrm{C} / \mathrm{EBP} \alpha$ and SREBP1c transcription factors, resulting in inhibition of lipid accumulation by blocking adipogenesis. Further studies will be needed to explore the regulation and function at the in vivo level.

\section{ACKNOWLEDGEMENTS}

This study was financially supported by Pusan National University in the program, Post-Doc. 2005.

\section{REFERENCES}

1. Kopelman PG. 1994. Causes and consequences of obesity. Med Int 22: 385-388.

2. Grundy SH. 1998. Muti-fratorial causation of obesity: implication for prevention. Am J Cli Nutr 67: 563-572.

3. Zhang Y, Proenca R, Maffei M, Barone M, Leopold L, Friedman JM. 1994. Positional cloning of the mouse obese gene and its human homologue. Nature 372: 425-432.

4. Haals JL, Gajiwala KS, Maffei M, Cohen SL, Chait BT, Rabinowitz D, Lallone RL, Burley SK, Friedman JM. 1995. Weight-reducing effects of the plasma protein encoded by the obese gene. Science 269: 543-546.

5. Campfield LA, Smith FJ, Guisez Y, Devos R, Burn P. 
1995. Recombinant mouse OB protein: evidence for a peripheral signal linking adiposity and central neural networks. Science 269: 546-549.

6. Haffiner SM, Gingerich RL, Miettinen H, Stern MP. 1996. Leptin concentrations in relations to overall adiposity and regional body fat distribution in Mexican Americans. Int J Obes Relat Metab Disord 20: 904-908.

7. Considine RV, Sinha MK, Heiman ML, Aidas K, Thomas WS, Mark RN, Joanna PO, Cheryl CM, Linda JM, Thomas LB, Jose FC. 1996. Serum immunoreactive-leptin concentrations in normal-weight and obese humans. $N$ Engl J Med 334: 292-295.

8. Lee TS, Chun MS, Choi JY, Noh BS. 1993. Changes of free sugars and free amino acids in kochujang with different mashing method. Food Biotechnol 2: 102-108.

9. Chun MS, Lee TS, Noh BS. 1994. The changes in capsaicin, dihydrocapsaicin and cansanthin in kochujang with different mashing methods. Food Biotechnol 3: 104-108.

10. Yoon JY, Jung KO, Kil JH, Park KY. 2005. Antiobesity effect of major Korean spices (red pepper powder, garlic and ginger) in rats fed high fat diet. J Food Sci Nutr 10: 58-63.

11. Oi Y, Kawada T, Shishido C, Wada K, Kominato Y, Nishimura S, Ariga T, Iwai K. 1999. Ally-containing sulfides in garlic increase uncoupling content in brown adipose tissue, and noradrenaline and adrenaline secretion in rats. J Nutr 129: 336-342.

12. McMahon FG, Vargas R. 1993. Can garlic lower blood pressure? A pilot study. Pharmacotherapy 13: 406-407.

13. Chang MW, Johnson MA. 1980. Effects of garlic on carbohydrate metabolism and lipid synthesis in rats. $J$ Nutr 110: 931-936.

14. Legnani C, Frascaro M, Guazzaloca G, Ludovici S, Cesarano G, Coccheri S. 1993. Effects of dried garlic preparation on fibrinolysis and platelet aggregation in health subject. Arzneimittelforschung 43: 119-122.

15. Lee HY. 2002. Preparation and fermentation characteristics of traditional kochujang and their cancer preventive and antiobesity effects. MS Thesis. Pusan National University, Korea.

16. Hardie L, Trayhurn P, Abramovich D, Fowler P. 1997. Circulating leptin in women; a longitudinal study in the menstrual cycle and during pregnancy. Clin Endocrinol 47: 101-106.

17. Maffei M, Halaas J, Ravussin E, Pratley RE, Lee GH, Zang Y, Fei H, Kim HS, Lallone R, Ranganathan S. 1995. Leptin levels in human and rodent: measurement of plasma leptin and RNA in obese and weigh-reduced subjects. Nat Med 1: 1155-1161.

18. Meister B. 2000. Control of food intake via leptin receptors in the hypothalamus. Vitam Horm 59: 265-304.

19. Rhee SH, Kong KR, Jung KO, Park KY. 2003. Decreasing effect of Kochujang on body weight and lipid levels of adipose tissues and serum in rats fed a high-fat diet. $J$ Korean Soc Food Sci Nutr 32: 882-886.

20. Choo JJ. 2000. Anti-obesity effects of Kochujang in rats fed on a high-fat diet. Korean J Nutr 33: 787-793.

21. Ly SY, Lee MR, Lee KA. 1999. Effects of cakes containing sponge oligosaccharides on blood lipids and intestinal physiology in rats. J Korean Soc Food Sci Nutr 28: 619624.

22. Lee HM, Chang UJ. 2001. Effect of corn peptide on the lipid metabolism in rats. Korean $J$ Dietary Culture 16: 416-422.

23. Ahn IS, Do MS, Kim SO, Jung HS, Kim YI, Kim HJ, Park KY. 2006. Antiobesity effect of Kochujang (Korean fermented red pepper paste) extract in 3T3-L1 adipocytes. J Med Food 9: 15-21.

24. Sivam GP. 2001. Protection against Helicobacter pylori and other bacterial infections by garlic. J Nutr 131: 11061108 .

25. Tsao SM, Yin MC. 2001. In vitro activity of garlic oil and four diallyl sulphides against antibiotic-resistant Pseudomonas aeruginosa and Klebsiella pneumoniae. $J$ Antimicrob Chemother 47: 665-670.

26. Avato P, Tursil E, Vitali C, Miccolis V, Candido V. 2000. Allylsulfide constituents of garlic volatile oil as antimicrobial agents. Phytomedicine 7: 239-243.

27. Chen GW, Chung JG, Ho HC, Lin JG. 1999. Effects of the garlic compounds diallyl sulphide and diallyl disulphide on arylamine N-acetyltransferase activity in Klebsiella pneumoniae. J Appl Toxicol 19: 75-81.

28. Chung JG. 1999. Effects of garlic components diallyl sulfide and diallyl disulfide on arylamine $\mathrm{N}$-acetyltransferase activity in human bladder tumor cells. Drug Chem Toxicol 22: $343-348$.

29. Shenoy NR, Choughuley AS. 1992. Inhibitionary effect of diet related sulphydryl compounds in the formation of carcinogenic nitrosamine. Cancer Lett 31: 227-232.

30. Ahman K. 2001. Historical perspective on garlic and cardiovascular disease. J Nutr 131: 977-979.

31. Kwon SK. 2003. Organosulfur compounds from Allium sativum and physiological activities. J Appl Pharm 11: 8-32.

32. Nascimento CO, Hunter L, Trayhurn P. 2004. Regulation of haptoglobin gene expression in 3T3-L1 adipocytes by cytokines, catecholamines, and PPAR $\gamma$. Biochem Biophys Res Commun 209: 250-256.

33. Cornelius P, MacDougald OA, Lane MD. 1994. Regulation of adipocyte development. Annu Rev Nutr 14: 99-129.

34. Guo X, Liao K. 2000. Analysis of gene expression profile during 3T3-L1 preadipocyte differentiation. Gene 251: 45-53.

35. Smith PJ, Wise LS, Berkowitz R, Wan C, Rubin CS. 1988. Insulin-like growth factor-I is an essential regulator of the differentiation of 3T3-L1 adipocytes. J Biol Chem 263: 9402-9408.

36. Tontonoz P, Hu E, Graves RA, Budavari AI, Spiegeman BM. 1994. mPPAR $\gamma 2$ : tissue-specific regulator of an adipocyte enhancer. Gene Dev 8: 1224-1234.

37. Rosen ED, Spiegelman H. 2000. Molecular regulation of adipogenesis. Annu Rev Cell Dev Biol 16: 145-171.

(Received March 17 2008; Accepted May 27, 2008) 